\title{
Comparison of HIF1 Gene Polymorphism (Rs11549465) Among Elite and Amateur Power Athletes Versus Non-athletes
}

Mohammad Reza Batavani ( $\sim$ batavani@iut.ac.ir)

Isfahan University of Technology https://orcid.org/0000-0002-5329-268X

Ghaedi Kamran

University of Isfahan

Original Research Article

Keywords: Hif1 gene, SNPs, Elite \& Amateur karate-kas, Non-athlete

Posted Date: June 10th, 2020

DOI: https://doi.org/10.21203/rs.3.rs-32905/v1

License: (c) (1) This work is licensed under a Creative Commons Attribution 4.0 International License.

Read Full License 


\section{Abstract}

Background: One of the major energy systems for power performance in muscles is glycolysis that is regulated by the levels of Hypoxia-inducible factor-1a (Hif1) which in response to hypoxia act as a transcription factor. The goal of this survey was the comparison of HIF1 gene polymorphism (rs11549465) among elite and amateur power karate-kas versus non-athletes.

Methods and Results: The C/T polymorphism allelic and genotypic's distribution of Hif1 rs11549465 gene was determined in this survey throughout 550 healthy Iranian subjects that divided in power karatekas groups that sub-divided into elite ( 86 male and 86 female) and amateur karate-kas (100 male and 72 female) versus 206 individuals in non-athlete group (100 male and 106 female). After obtaining the written consent of all participants in the study, in seated mode, at a given time and in the diagnosticlaboratory, the amount of $5 \mathrm{cc}$ blood from brachiocephalic vein was taken. The Hif1 gene T/C polymorphism was assessed with PCR by using the forward and the overturn primers. Amplicons, the length were treated with the restriction endonuclease $\mathrm{Hph}$ I (Enzyme). Also RFLP were analyzed by electrophoresis separation on $1 \%$ agarose gel. Non-parametric Chi-Square and multinomial regression tests were used for assess the differences through the SPSS software and the P value less than 0.05 was considered as a significant different. Chi-square test showed genotype frequencies of Hif1 TC rs 11549465 (TC genotype: $25.6 \%$ vs. TT genotype: $11.4 \%$; CC genotype: $63 \%$ ) were significantly different in these population $\left(X^{2}=99.889, P=0.000\right)$. Furthermore, the results of multiple regressions demonstrated that there isn't general linear relationship between Hif1 gene expression and power ability of karate-kas.

Conclusions: From the genetic talent aspect, there wasn't any correlation between Hif1 gene expressions with Iranian karate competitor's levels.

\section{Key Points:}

Genetic and environmental factors have a great influence over components of the athletic performance such as power/ strength traits.

Genetic markers may increase comprehension of athlete talent.

There wasn't any correlation between Hif1 gene expressions with Iranian karate competitor's levels.

\section{Introduction}

Genetic factors have major effects on elements of the athletic performance like psychological traits and phenotypes (1). Evidence suggested that genetic markers may explain variation of physical performance specs in reply to endurance or strength training (2). For example, there are valid roles for genetic research and the Australian Institute of Sport (AIS) valid genetic study which aims to increase comprehension of athlete talent to injury or illness (3). Nowadays many commercial companies being predict athletic ability throughout genetic testing. Polymorphisms identifying sport talent (genetic testing) could revolutionary to 
the field of physical performance (4). The result of sport talent is identify athletes suitable to the specs of the sportive branch selected (5); so sport talent companies may explore the might of initial success for sportsmen partly on genetic database. Hence, genetic sport talent can bring many benefits from economic efficiency and success, likely. For this reason, the SNPs were investigated in order to expedite the choice process for talented individuals who wish to be a huge champion. Although be notice that due to much number of SNPs related to sport performance and much cost of review them, we may not be able to test all of them, therefore it needs to provide exact survey to ensure the correct relation information for each famous sport that be rely about it via genetic sport talent.

Exercise condition increases oxygen demand which is required in muscle contraction (6). Glycolytic system is one of the most important energy supplies of skeletal muscles during highly intense exercise under anaerobic performance in sport. This imbalance condition between the amounts of oxygen demand and supply in body is named hypoxia (6). There is a hypothesis that continuous exercise training induced hypoxia, as a beneficial muscular adaptations, would result in induce included increased expression of genes that codes glycolysis enzymes (7). Hypoxia via the expression of peroxisome proliferator activated receptor-gamma coactivator 1a (PGC-1a) regulates the HIF-1a (8). Likely, HIF1a initiates the transcription of various hypoxia-adaptive genes like glycolysis, hence improves glucose metabolism (9). The Pro582Ser polymorphism (rs11549465) was detected in the HIF1A gene that encodes a subunit of HIF-1 protein, resulting in the replacement of proline (Pro) with serine (Ser) at amino acid 582 (10). Pro582Ser is present in exon 12 (C/T at bp 85; rs11549465) and T allele (Ser582) improves glucose metabolism (1). The HIF1A Ser allele can be associate with allele favoring the development of the speed/ power capacity; hence it subdivided in power/strength-related genetic markers. It is reported that increased ratio of fast-twitch muscle fibers in Vastus Lateralis was associated by 582Ser allele (11).

Karate is one of the most competitive sports in Olympic. Base on the world karate federation rules, the first qualify punch or kick of competitors; result in the point and the next punch or kick of his/her opponent will not get the score; even though they be correct. So, high speed of karate-ka among the other kind of fitness factors would be important for each elite karate-ka, and hence, this kind of sport would appropriate in power/strength-related sport (Batavani et al. unpublished data).

To date, Ahmetov et al (2008) reported that the frequency of the HIF1A 582Ser allele in Russian weightlifters vs. controls was significantly higher and increase of its frequency had association with their competition levels (11). Also Cięszczyk et al (2011) reported that the incidence of the HIF1A Ser allele genotype polymorphism in power-orientated runners, swimmers and weightlifters was significantly higher than sedentary controls, too (12). These results were ingeminate by Gabbasov et al (2013) in Russian weightlifters and wrestlers and Drozdovska (2013) in Ukrainian power-oriented athletes $(13,14)$. But Eynon et al (2011) didn't get same result in sprinters as well as Mounier et al (2009) showed the significant decrease in HIF-1a mRNA after hypoxic training, too $(15,7)$.

Regardless contradictory in previews' researches, yet there is clearance that would be the linear relationships between genotype of Hif1 gene polymorphism rs11549465 structures and power 
performance ability in Iranian population, too? Of course in a deep view of the physiological role of Hif1 gene polymorphism rs11549465, its higher amount expression in elite karate-kas, would represents it as a qualify nominees of gene talent and reception of the relationships between Hif1 and success in Iranian karate-kas. So, our study examined the comparison of HIF1 gene polymorphism rs11549465 among Iranian elite /amateur power strength karate-kas vs. non-athletes, representing the possible association of genotype with karate performance.

\section{Methods}

This survey was done on 550 Iranian subjects (age $27.2 \pm 7.4$ years [mean \pm sd]) include of 344 karate competitors (male; $n=186$; female, $n=158$ ) (subdivided in Kata $=17.3 \%$; Kumite $=76.8 \%$ and both Kata/Kumite $=5.9 \%$ branches) that were divided in elite (172 elite [male: $n=86$ \& female: $n=86] ;+172$ amateur competitors [male: $n=100$ \& female: $n=72$ ]) compare with 206 non-athletes (male; $n=100$; female, $\mathrm{n}=106)($ Table1).

Table 1

Subject's biographic characteristics

\begin{tabular}{|c|c|c|c|c|c|c|c|c|c|}
\hline \multirow[t]{2}{*}{ Group } & \multirow[t]{2}{*}{ Frequency } & \multicolumn{2}{|c|}{ Sex (No) } & \multicolumn{3}{|c|}{ Category (\%) } & \multirow{2}{*}{$\begin{array}{l}\text { Weight } \\
\text { (kg) } \\
\text { Mean } \pm \\
\text { Sd }\end{array}$} & \multirow{2}{*}{$\begin{array}{l}\text { Height } \\
\text { (cm) } \\
\text { Mean } \pm \\
\text { Sd }\end{array}$} & \multirow{2}{*}{$\begin{array}{l}\text { Age } \\
\text { (year) } \\
\text { Mean } \\
\pm \text { Sd }\end{array}$} \\
\hline & & Female & Male & Kata & Kumite & Both & & & \\
\hline Elite & 172 & 86 & 86 & \multirow[t]{2}{*}{$17 / 3$} & \multirow[t]{2}{*}{$76 / 8$} & \multirow[t]{2}{*}{$5 / 9$} & $\begin{array}{l}64 / 3 \pm \\
1 / 1\end{array}$ & $\begin{array}{l}169 \pm \\
4 / 2\end{array}$ & \multirow[t]{3}{*}{$\begin{array}{l}27.2 \pm \\
7.4\end{array}$} \\
\hline Amateur & 172 & 72 & 100 & & & & $\begin{array}{l}66 / 9 \pm \\
2 / 2\end{array}$ & $\begin{array}{l}171 \pm \\
2 / 9\end{array}$ & \\
\hline $\begin{array}{l}\text { Non- } \\
\text { athlete }\end{array}$ & 206 & 106 & 100 & - & - & - & $\begin{array}{l}67 / 6 \pm \\
1 / 7\end{array}$ & $\begin{array}{l}171 \pm \\
5 / 2\end{array}$ & \\
\hline \multirow[t]{2}{*}{ Total } & \multirow[t]{2}{*}{550} & \multirow[t]{2}{*}{264} & \multirow[t]{2}{*}{286} & \multirow{2}{*}{\multicolumn{3}{|c|}{$\begin{array}{l}\text { Comparisons of Means } \\
\text { (weight, height \& age): }\end{array}$}} & $\begin{array}{l}F= \\
1 / 97\end{array}$ & $\begin{array}{l}F= \\
0 / 794\end{array}$ & $\begin{array}{l}F= \\
2 / 649\end{array}$ \\
\hline & & & & & & & $\begin{array}{l}\text { Sig }= \\
0 / 141\end{array}$ & $\begin{array}{l}\text { Sig }= \\
0 / 453\end{array}$ & $\begin{array}{l}\text { Sig }= \\
0 / 072\end{array}$ \\
\hline
\end{tabular}

Elite karate-kas had experience of membership of national karate teams (from each age groups of Junior, youth or senior teams) that were reached the championship or good places in the world, Asian, international or national competitions in last decade. 7 karate-kas were world or Asian championships; 50 karate-kas had international medal and 115 one of them had successfully in Iran karate championship as their athletic experience. Amateur karate-kas took parted in karate training at least 4 years and had upgraded their rankings to the black belt, but they hadn't get to the elite group's places. Subjects in the control group didn't have any regular exercise experience in their life.

The methods of sampling were explained to the subjects and they signed their written consent form to participate in the survey. The patient samples were excluded out from the survey. Besides, all people with 
familial relation were left out from survey; and bioethics items were considered relying on the standards described by advisory board of the faculty of sport sciences. In seated mode, at a given time and in the diagnostic-laboratory, the amount of $5 \mathrm{cc}$ blood from brachiocephalic vein was taken and according to the alkali treatment protocol genome was isolated (16).

\section{DNA isolation.}

In this study salting-out method was used for DNA extraction. All of samples were kept at $4{ }^{\circ} \mathrm{C}$. Then, the amount of $0 / 5 \mathrm{ml}$ of blood sample with cell lysis buffer add to micro tube $(1.5 \mathrm{ml}), 15$ minutes was incubated by ice that result to fragility on the membrane of red blood cells and centrifuged at $9000 \mathrm{rpm}$ for $5 \mathrm{~min}$, hence $\otimes$ of the supernatant discarded and cell lysis buffer was added. After 10 minutes of incubation, 5 minutes centrifuged at $9000 \mathrm{rpm} 5$ times until the time of observation white pink pellet. The produced pellet by nuclease lysis buffer (to lysing the membrane of nucleus) was dissolved. Then sodium per chlorate was added and cloudy protein made. chloroform was added then at $12000 \mathrm{rpm}$ for 10 minutes centrifuged. Ethanol (96\%) was added to water phase of tube that was contained DNA, then it was shacked again. by observing the DNA cluster, tube at $12000 \mathrm{rpm}$ was centrifuged for 10 minuted, then ethanol (70\%) was added, again at $12000 \mathrm{rpm}$ centrifuged for 10 minutes. After drying the tube at room temperature, sterile distilled water was added and extracted DNA was placed at $-20{ }^{\circ} \mathrm{C}(17)$.

\section{Quality checking of isolated DNA}

By the spectrophotometer and measured via the ratio of DNA optical density (A260) and protein optical density (A280) the concentration and purity of the extracted DNA were analyzed. also for determining of DNA degradation, electrophoresis was performed on $1 \%$ agarose gel, too.

\section{Analysis of DNA amplification and restriction fragment length polymorphism (RFLP)}

Via PCR using a specific primer pair (the forward primer, 5'_AGGACACAGATTTAGACTTGG_3'; the overturn primer, 5'_GGAATACTGTAACTGCGCTTTG_3) and the enzyme of Hph I the HIF-1a gene T/C polymorphisms were determined. The PCR reaction was done at a volume of $25 \mu$ including $1 \mu l$ extracted genome (100ng) as template and $0.2 \mu \mathrm{M}$ of each primer, $0.2 \mathrm{mM}$ each of deoxynucleotidetriphosphate (CinnaGen Co.), $1.25 \mathrm{U}$ Smar taq DNA polymerase (CinnaGen Co.), and 4mM Mg2+ (Cinnagen Co.). PCR protocol was include of primary denaturation phase via 1 cycle for 5 min at $94^{\circ} \mathrm{C}, 35$ repetitive amplification cycles including $30 \mathrm{Sec}$ at $94^{\circ} \mathrm{C}, 45 \mathrm{Sec}$ at $56^{\circ} \mathrm{C}$ and $30 \mathrm{Sec}$ at $72^{\circ} \mathrm{C}$ as denaturation, annealing and extention phases; and final cycle for $10 \mathrm{~min}$ at $72^{\circ} \mathrm{C}$ as final extention phase. Amplicons, $150 \mathrm{bp}$ in length were treated via the restriction endonuclease Bsp/9l (SibEnzyme). A 150 bp fragment corresponded to the Allele was able to cut producing100- and50-bp fragments. The length of fragment in 150 demonstrated as $\mathrm{T} / \mathrm{T}$ genotype and the length of fragments in 100 and 50 demonstrated as $\mathrm{C} / \mathrm{C}$ genotype, and the length of fragments in 50, 100 and 150 demonstrated T/C genotype. In 1\% Agarose gel, the RFLP were analyzed by electrophoresis separation followed by staining via ethidium bromide and visualization in transmitted ultraviolet light. 


\section{Analyses of Data.}

The graphs are drawn via Graph Pad in Stat and figure is drawn via Excel software, too. Non-parametric Chi-Square and multinomial regression tests were used for assess the differences through the SPSS software and the $P$ value less than 0.05 was considered as a significant different. Confidence interval is $95 \%$ and for greater certainty the multinomial regression test was used.

\section{Results}

Quantitative analysis of DNA samples by spectrophotometer for 5 samples (typical) on agarose gel $1 \%$ has been shown (Fig. 1). The extracted DNA concentration was between 130 and $440 \mathrm{ng} / \mu \mathrm{l}$ and the absorption ratio of $260 \mathrm{~nm}$ to $280 \mathrm{~nm}$ of the samples ranged from 1.8 to 1.96 .

PCR products were led to diagnosis of the types of the allele (T/T: in length of $150 \mathrm{bp}, \mathrm{C} / \mathrm{C}$ in length of $100 \mathrm{bp}$ and $50 \mathrm{bp}$, and C/T in length of 100, $50 \& 150 \mathrm{bp}$ ) and genotype of some subjects (Fig. 2).

Genotype and allelic frequencies analyses by the HIF1gene (T/C polymorphism) in karate-kas and nonathletes have showed that the CC genotype (63\%) had the most common incidence, while the TT genotype (11.4\%) and TC genotype (25.6\%) were less common. Totally, Chi-Square tests demonstrated that there is a significant difference in frequencies of HIF1 gene allelic $(\chi 2=99.889, p=0.000)$.

Table 2

Distribution analyses of genotype frequencies by the HIF1gene(T/C polymorphism) in all subjects

\begin{tabular}{|c|c|c|c|c|c|c|}
\hline Genotype & Observed \% & Expected \% & Residual & Df & Chi-Square & Asymp. Sig. \\
\hline TT & 11.4 & 33.3 & -51.3 & 2 & 99.889 & $P=0.000$ \\
\hline $\mathrm{TC}$ & 25.6 & 33.3 & -18.3 & & & \\
\hline CC & 63 & 33.3 & 69.7 & & & \\
\hline Total & 100 & 100 & & & & \\
\hline
\end{tabular}

The distribution of genotype and allele frequencies had the same pattern when it subdivided sexually, too. The distribution in female (CC: $59.9 \%$; TT: $13.6 \%$ and TC: $26.5 \%$ ) and in male (CC: $66.1 \%$; TT: $9.3 \%$ and TC: $24.6 \%)$ were significantly different $\left(\chi^{2}=39.846, p=0.000 ; \chi^{2}=61.136, p=0.000\right)$ respectively. Also Mann-Whitney Test showed there was no significant difference in total HIF1 allelic gen between male and female (Mann-Whitney U=6.408E3, $p=0.267$ ) (Table3; Fig. 3). 
Table 3

Sexually distribution analyses of genotype frequencies by the HIF1gene(T/C polymorphism) in all subjects

\begin{tabular}{|c|c|c|c|c|c|c|c|c|}
\hline Sex & Genotype & $\begin{array}{l}\text { Observed } \\
\%\end{array}$ & $\begin{array}{l}\text { Expected } \\
\%\end{array}$ & Residual & Df & $\begin{array}{l}\text { Chi- } \\
\text { Square }\end{array}$ & $\begin{array}{l}\text { Mean } \\
\text { Rank }\end{array}$ & $\begin{array}{l}\text { Mann- } \\
\text { Whitney U } \\
\text { P Value }\end{array}$ \\
\hline \multirow[t]{4}{*}{ Female } & TT & 13.6 & 33.3 & -23.0 & \multirow[t]{4}{*}{2} & \multirow{4}{*}{$\chi^{2}=39.846$} & \multirow[t]{4}{*}{113.77} & \multirow{8}{*}{$\begin{array}{l}\text { Asymp. } \\
\text { Sig. }(2- \\
\text { tailed)= } \\
0.267\end{array}$} \\
\hline & $\mathrm{TC}$ & 26.5 & 33.3 & -8.0 & & & & \\
\hline & $\mathrm{CC}$ & 59.9 & 33.3 & 31.0 & & & & \\
\hline & Total & 100 & 100 & & & & & \\
\hline \multirow[t]{4}{*}{ Male } & TT & 9.3 & 33.3 & -28.3 & \multirow[t]{4}{*}{2} & \multirow[t]{2}{*}{$\chi^{2}=61.136$} & \multirow[t]{4}{*}{122.19} & \\
\hline & TC & 24.6 & 33.3 & -10.3 & & & & \\
\hline & $\mathrm{CC}$ & 66.1 & 33.3 & 38.7 & & \multirow[t]{2}{*}{$P=0.000$} & & \\
\hline & Total & 100 & 100 & & & & & \\
\hline
\end{tabular}

The distribution of genotype and allele frequencies had the same pattern when it subdivided in elite and amateur karate-kas and non-athletes, too. The distribution in elite (CC: $67.3 \%$; TT: $7.7 \%$ and TC: $25 \%$ ) and in amateur (CC: 61.5\%; TT: 9.6\% and TC: $28.9 \%$ ) and non-athletes (CC: 61.6\%; TT: $15.2 \%$ and TC: $23.2 \%$ ) were significantly different $\left(\chi^{2}=41.830, p=0.000 ; \chi^{2}=39.224 ; \chi^{2}=53.128, p=0.000\right.$ ) respectively (Figure 3). But non-parametric Chi-Square test showed there wasn't significant difference between elite, amateur and non-athlete groups $\left(X^{2}=2.745\right.$, Asymp Significant (2-sided): $\left.P>0.05\right)$.

Result showed HIF1 gene T/C polymorphism is not significantly associated with the physical performance's levels of karate-kas in Iranian population. The frequency of T/T genotype vs. C/C genotype decrease in professional karate-kas and amateur karate-kas versus to control non-athletes (odd ratio $<1)$, but it wasn't significant $(P>0 / 05)$. Also the frequency of $T / C$ genotype vs. $C / C$ genotype increase in professional karate-kas and amateur karate-kas versus to control non-athletes (odd ratio $>1$ ), and however it was not significant, too $(P>0 / 05)$. Odd ratio of $T / T$ and $T / C$ genotype compare to $C / C$ in professional group versus control were 0.631 (Cl: 0.262 - 1.516) and $1.363(\mathrm{Cl}: 0.750-2.476)$ respectively. Odd ratio of T/T and T/C in amateur group versus control were 0.831 (Cl: $0.417-1.656)$ and 1.198 (Cl: $0.703-2.040$ ) respectively (Table4). 
Table 4

Multinomial logistic regressions for rs11549465 genotype distribution in professional, amateur karate-kas and non-athlete groups

\begin{tabular}{|c|c|c|c|c|}
\hline \multicolumn{3}{|c|}{ Condition ${ }^{a}$} & \multicolumn{2}{|c|}{ 95\% Confidence interval for $\operatorname{Exp}(B)$} \\
\hline & & Odd Ratio & Lower Bound & Upper Bound \\
\hline \multirow[t]{3}{*}{ Elite } & HIF1 gene = T $/ \mathrm{T}$ & 0.631 & .556 & 2.275 \\
\hline & HIF1 gene $=\mathrm{T} / \mathrm{C}$ & 1.363 & .538 & 1.984 \\
\hline & HIF1 gene $=\mathrm{C} / \mathrm{C}$ & 1.000 & . & . \\
\hline \multirow[t]{3}{*}{ Amateur } & HIF1 gene $=\mathrm{T} / \mathrm{T}$ & 0.831 & .535 & 1.876 \\
\hline & HIF1 gene = T / C & 1.198 & .715 & 2.205 \\
\hline & HIF1 gene $=\mathrm{C} / \mathrm{C}$ & 1.000 & . & . \\
\hline
\end{tabular}

\section{Discussion}

This survey compared HIF1 gene polymorphism rs11549465 among elite/ amateur power athletes vs. non-athletes. Analyze showed that the HIF1 gene TC genotype occurrence in Iranian population (elite and amateur karate-kas and non-athletes, in both male and female) were significantly different among high incidence of CC, TC and TT; respectively. It's worth noting that HIF1 genotype frequency and T/C allele occurrence incidence between all groups (among elite, amateur and non-athlete) were not statistically differences significant and wasn't associated with the physical performance's levels of karate-kas.

Our results were in confirm by the results that reported by Eynon et al. (2011) that did not find significant differences in their survey in HIF1A genotype distribution and Ser582 allele frequency of endurance and sprinters athletes vs. controls (15). These results showed that HIF1A Ser allele carriers are not more predisposed to power-orientated karate-kas.

Our survey doesn't confirm previews studies by Ahmetov et al (2008) that reported a association between the HIF1A Pro582Ser polymorphism and increased levels of Russian sprint/strength weightlifters achievement and Zoll et al. (2006) that showed long exercise plan (i.e., 6 weeks) significantly (up to $104 \%)$ increased hif-1 gene expression in Quadriceps muscle, too $(11,18)$.

Differences in the sports conditions, training design (frequency and duration), methods of DNA extraction, size of subjects, and experience and training sessions of subjects, etc...could explain these discrepancies, likely. Especially our study, had blood sampling protocol instead of muscle biopsies. Mounier et al (2009) found decrease in transcriptional regulations of the hif-1 a gene when they used muscle biopsy; while it 
didn't change when they had blood sampling to extract DNA (7). In our survey DNA was extracted from peripheral blood samples.

Differences in races of subjects (i.e. Russian [Ahmetov et al; 2008] and Polish [Cięszczyk; 2011] groups) and multiple sportive field of subjects (i. e. Runners/ Swimmers/ Weightlifters together in some mentioned surveys) are another possible explanation, too $(11,12)$. In the studies by Khaledi et al $(2014)$ on Iranian professional athletes (include of Olympic and world championship in variant branches) vs. non-athletes about ACTN3, PGC-1a, ACE, CKMM, PPARy polymorphisms, and Salehi et al (2011) on 148 Iranian national teams (in different sports) vs. 175 non-athletes aboutACTN3, didn't find significant differences, too (19).

Semenza (2010) narrated that HIF-1a protein stability is regulated by the mechanisms that are oxygenindependent (20). Cooper et al (2007) reported that acute exercise is attended by reduced partial pressure of oxygen, too (21). Oxygen privation, among erythropoietin (EPO), VEGF and HIF-1a modulates several genes of oxygen homeostasis (22). Hypoxia condition product the ROS that likely reduce Fe2+ availability, which inhibits the activity of factor inhibiting HIF-1 (6).

In the state of hypoxia many factors such as the amount of ATP in muscles, high enzymatic performance for energy supply via glycolysis and phosphagenic systems, creatine phosphate, glycogen, etc... affecting the high anaerobic ability (11).

From the other hand, a complex interaction of psychological, socio-cultural, and etc factors result in variation of athletic performance (23). Mitchell et al (2005) reported that karate-Do is a low dynamic and high static sport; hence it need moderate total cardiovascular demands, too (24). Aligned with it Batavani et al (2017) had been proposed to be the association between the CK-MM gene A/G genotype and brilliant karate-kas performance (19). Aerobic energy supply and power ability of muscles among exercise are important, too. Indeed elite karate performance is a polygenic trait, with over one polymorphism like ACE and CKMM association (19). Also, elite performance in karate seems depends on the simultaneous presence of multiple fitness factors such skill, speed and etc..., likely.

Indeed might be having a suggestion that the HIF1A Pro582Ser polymorphism is not important in karate athletes. Hence, for some branches of sport which are yielded by intensive training, suitable genetic is not enough to attach the optimal sport performances, basically. However, the effect of genes for adaptation and responding to exercise, unable to be ignored (25). Athletic performance that predicted by genetic profiles examination alone, is not reliably (26). The most branches of sports need the combination of sprint or power and endurance demands together such as many other factors, including a broad variety of genetic, physical, environmental and psychological elements to reach the success, too (3). Specially, it be suggested that between the HIF1 gene polymorphism and athletic status replicate additional large scale prospective studies in some worldwide branches of sports, separately. However, this conclusion needs to be supported by more experimental surveys about HIF1A polymorphisms in professional athletes. Döring et al (2010) and Mason et al (2007) have written the articles about the role of the HIF1A gene as a genetic marker associated with endurance athlete performance, too $(27,28)$. 


\section{Conclusion}

Our study investigated the relation among the HIF1A Pro582Ser polymorphism and karate performance. The investigated group included of elite and amateur karate-kas, and the results of our survey did not indicate the relation between HIF1A Ser 582 allele and karate level achievement. Indeed, the findings showed no association between HIF1A gene Pro582Ser polymorphism and Iranian karate-kas performance. Therefore it suggested that the HIF1A gene can't be taken into consideration as a genetic marker in Iranian power-orientated karate-kas. Hence that genetic association studies must be interpreted with caution, likely and the accordingly use of Hif1 genetic experiments as an only predictor of karate talent is unscientific and invalid.

\section{Abbreviations}

SNP: Single nucleotide polymorphism; HIF1: Hypoxia-inducible factor-1; PCR: Polymerase Chain Reaction; RFLP: Restriction Fragment Lengths of the Products; CKMM: Muscle-Specific Creatine Kinase; ACE: Angiotensin converting enzyme; Ser: Serine; Pro: Proline

\section{Declarations}

\section{Acknowledgements}

The authors would like to thank all staff within the office of vice chancellor for research and technology of the Isfahan University of technology for their continuing help and support with this manuscript and thank all karate-kas and participants for their participation.

\section{Authors' Contributions}

GK + BMR were responsible for the study design, protocol development and protocol writing and financing. BMR wrote the main manuscript and GK edited, finally all authors read and confirmed this final article.

\section{Funding}

No funding was received for this manuscript.

\section{Availability of Data and Materials}

A blind summary of the dataset that was analyzed during this survey are available from the corresponding author when requested.

\section{Ethics Approval and Consent to Participate}

The data usage was approved by Isfahan karate province and the Research Ethics Service at the University of Isfahan. Before the blood sampling, the protocol of survey was explained to participants and 
all of them signed their written consent form to participate in this survey, too.

\section{Consent for Publication}

Both authors have read the article and confirmed the final version.

\section{Competing Interests}

The authors Batavani Mohammad Reza and Ghaedi Kamran, declare that they have no competing interests.

\section{Author details}

${ }^{1}$ Department of Physiology, Faculty of Center of Physical Education, Isfahan University of Technology, Isfahan 84156-83111, Iran, ${ }^{2}$ Department of Cell and Molecular Biology and Microbiology, Faculty of Biological Science and Technology, University of Isfahan, Iran

\section{Publisher's Note.}

Springer Nature remains neutral with regard to jurisdictional claims in published maps and institutional affiliations.

\section{References}

1. Ahmetov, I. I., \& Fedotovskaya, O. N. (2015). Current Progress in Sports Genomics. Advances in Clinical Chemistry.Doi: https://doi.org/10.1016/bs.acc.2015.03.003

2. Bray, M.S.Hagberg, J.M. Pe'russe, L. Rankinen, T. Roth, S.M. Wolfarth, B. Bouchard, C. (2009) The human gene map for performance and health-related fitness phenotypes: the 2006-2007 update, Med. Sci. Sports Exerc. 41 34-72. DOI: 10.1249/MSS.0b013e3181844179

3. Vlahovich, N., Fricker, P. A., Brown, M. A., \& Hughes, D. (2017). Ethics of genetic testing and research in sport: a position statement from the Australian Institute of Sport. British journal of sports medicine, 51(1), 5-11. http://dx.doi.org/10.1136/bjsports-2016-096661

4. MacArthur DG, North KN, (2005), Genes and human elite athletic performance. Hum Genet:;116:3319. https://doi.org/10.1007/s00439-005-1261-8

5. Ozveren Y, Ozcaldiran B, Durmaz B, Oral O, (2014), Talent selection and genetics in sport, Turkish Journal of Sport and Exercise, Volume: 16 - Issue: 2 - Pages: 1-8, DOI: 10.15314/TJSE.201428098

6. Sylviana N, Helja N, Hudanul H Q, Goenawan H, Lesmana1 R, Rizky M et al, (2018), Effect of Swimming Exercise to Cardiac PGC-1 and HIF-1 Gene Expression in Mice, Asian J Sports Med. 9(4):e65079, doi: 10.5812/asjsm.65079

7. Mounier, R., Pialoux, V., Roels, B., Thomas, C., Millet, G., Mercier, J., ... \& Clottes, E. (2009). Effect of intermittent hypoxic training on HIF gene expression in human skeletal muscle and 
leukocytes. European journal of applied physiology, 105(4), 515.doi:

https://doi.org/10.1007/s00421-008-0928-y

8. Jung S, Kim K. (2014), Exercise-induced PGC-1alpha transcriptional factors in skeletal muscle. Integr Med Res.;3(4):155-60. doi:10.1016/j.imr.2014.09.004. [PubMed: 28664092]. [PubMed Central: PMC5481761].

9. Sutter C H. Laughner E, and Semenza G L, (2000), Proc. Natl.Acad. Sci. USA, No. 9, 4748-4753.

10. Clifford S.C., Astuti D., Hooper L., Maxwell P.H., Ratcliffe P.J., Maher E.R. (2001), The pVHL associated SCF ubiquitin ligase complex: molecular genetic analysis of elongin $B$ and $C, R b x 1$ and HIF-1alpha in renal cell carcinoma. Oncogene;20:5067-5074.DOI: https://doi.org/10.1038/sj.onc.1204602

11. Ahmetov I I, Hakimullina A M, Lyubaeva E V, Vinogradova O L, Rogozkin V A, (2008), Effect of HIF1A gene polymorphism on human muscle performance, Bull. Exp. Biol. Med. 146 351-353.Doi: https://doi.org/10.1007/s10517-008-0291-3

12. Cieszczyk P, Sawczuk M, Maciejewska A, Ficek K, Eider J, (2011), Variation in peroxisome proliferator activated receptor a gene in elite combat athletes, Eur. J. Sport Sci. 11 119-123. https://doi.org/10.1080/17461391.2010.487120

13. Gabbasov R T, Arkhipova A A, Borisova A V, Hakimullina A M, Kuznetsova A V, Williams A G, et al, (2013), The HIF1A gene Pro582Ser polymorphism in Russian strength athletes, J. Strength Cond. Res. 27 2055-2058. doi: 10.1519/JSC.0b013e31827f06ae

14. Drozdovska, S. B., Dosenko, V. E., Ahmetov, I. I., \& Ilyin, V. (2013). The association of gene polymorphisms with athlete status in Ukrainians. Biology of sport, 30(3), 163.

doi: $10.5604 / 20831862.1059168$

15. Eynon N., Meckel Y., Alves A.J., Nemet D., Eliakim D. (2011), Is there an interaction between BDKRB2-9/+9 and GNB3 C825T polymorphisms and elite athletic performance? Scand. J. Med. Sci. Sports, Jan 7. doi : 10.1111/j.1600-0838.2010.01261.x.

16. Martínez J, Khorsandi S, Sojo R, Martínez C, Martín, JA, López-Taylor JR, etal. (2009), Lack of an association between CKMM genotype and endurance performance level in Hispanic marathon runners. MedicinaSportiva.;13(4), 219-223.

17. Shokrzadeh, M; Mohammadpour, A. (2018), Evaluation of a modified salt-out method for DNA extraction from whole blood lymphocytes: A simple and economical method for gene polymorphism." Pharmaceutical and Biomedical Research 4, no. 2: 28-32. DOI:

10.18502/pbr.v4i2.218

18. Zoll J, Ponsot E, Dufour S, Doutreleau S, Ventura-Clapier R, Vogt M, Hoppeler H, et al.(2006). Exercise training in normobaric hypoxia in endurance runners. III. Muscular adjustments of selected gene transcripts. J Appl Physio/ 100: 1258-1266. https://doi.org/10.1152/japplphysiol.00359.2005

19. Batavani, M. R., Marandi, S. M., Ghaedi, K., \& Esfarjani, F. (2017). Comparison of muscle-specific creatine kinase (CK-MM) gene polymorphism (rs8111989) among professional, amateur athletes and non-athlete karatekas. Asian Journal of Sports Medicine, 8(2).DOI : 10.5812/asjsm.43210

20. Semenza GL, (2010), Oxygen homeostasis. Wiley Interdiscip Rev Syst Biol Med 2: 336-361. 
21. Cooper DM, Radom-Aizik S, Schwindt C, Zaldivar F Jr. 2007. Dangerous exercise: lessons learned from dysregulated inflammatory responses to physical activity. J Appl Physio/ 103: 700-709.DOI: 10.1152/japplphysiol.00225.2007

22. Lemus-Varela ML, Flores-Soto ME, Cervantes-Munguia R, Torres-Mendoza BM, Gudino- abrera G, Chaparro-Huerta V, et al. (2010), Expression of HIF-1 alpha, VEGF and EPO in peripheral blood from patients with two cardiac abnormalities associated with hypoxia. Clin Biochem.;43(3):234-9. doi: 10.1016/j.clinbiochem.2009.09.022. [PubMed:19804771].

23. Brutsaert, T. D., \& Parra, E. J. (2006). What makes a champion?: Explaining variation in human athletic performance. Respiratory physiology \& neurobiology, 151(2), 109-123.

https://doi.org/10.1016/j.resp.2005.12.013

24. Mitchell J, Haskell W, Snell P, Van Camp S. (2005), Classification of sports, J Am CollCardiol.; 45(8):1364-7. DOI: 10.1016/j.jacc.2005.02.015

25. Lippi G, Longo U, and Maffulli N. (2010), Genomics and sports. Br Med Bull:;93:27-47.

26. Guilherme JPLF, Tritto ACC, North KN, et al. (2014), Genetics and sport performance: current challenges and directions to the future. Revista Brasileira de Educação Física e Esporte;28:177-93 https://doi.org/10.1590/S1807-55092014000100177

27. Döring F., Onur S., Fischer A., Boulay M.R., Pérusse L., Rankinen T., et al, (2010), common haplotype and the Pro582Ser polymorphism of the hypoxia-inducible factor-1a (HIF1A) gene in elite endurance athletes. J. Appl. Physiol; 108:1497-1500. https://doi.org/10.1152/japplphysiol.01165.2009

28. Mason S.D., Rundqvist H., Papandreou I., Duh R., McNulty W.J., Howlett R.A., et al (2007), HIF-1a in endurance training: suppression of oxidative metabolism. Am. J. Physiol.;293:2059-2069.

\section{Figures}

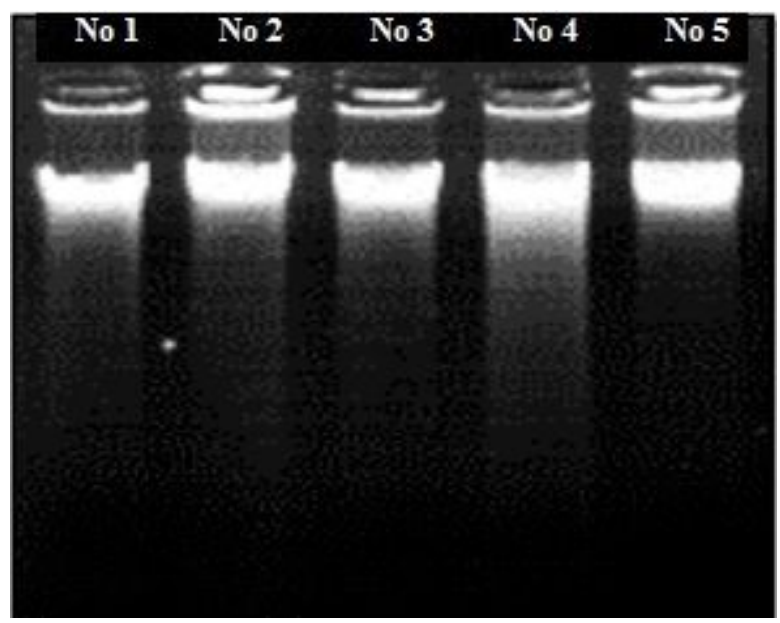

Figure 1

Quantitative analysis of DNA of 5samples by spectrophotometer on agarose gel $1 \%$ 


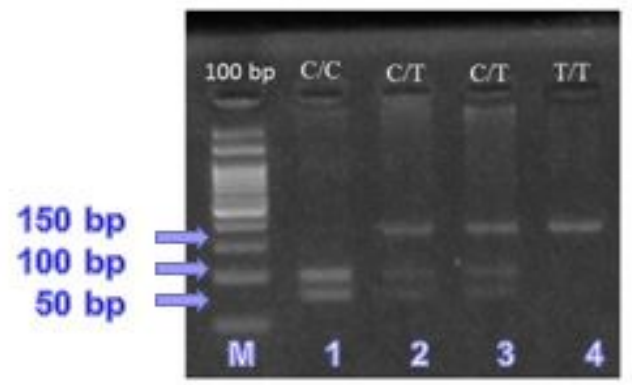

\section{Figure 2}

Representative of an agaros gel electrophoresis of PCR partial products of HIF1 gene. Lane 1; CC genotype (100 \& $50 \mathrm{bp}$ ) and lanes 2, 3; CT genotype (50, $100 \& 150 \mathrm{bp}$ ) and lane 4; TT genotype (150bp). Lane $\mathrm{M}$ is DNA 100 bp ladder (Fermentas).

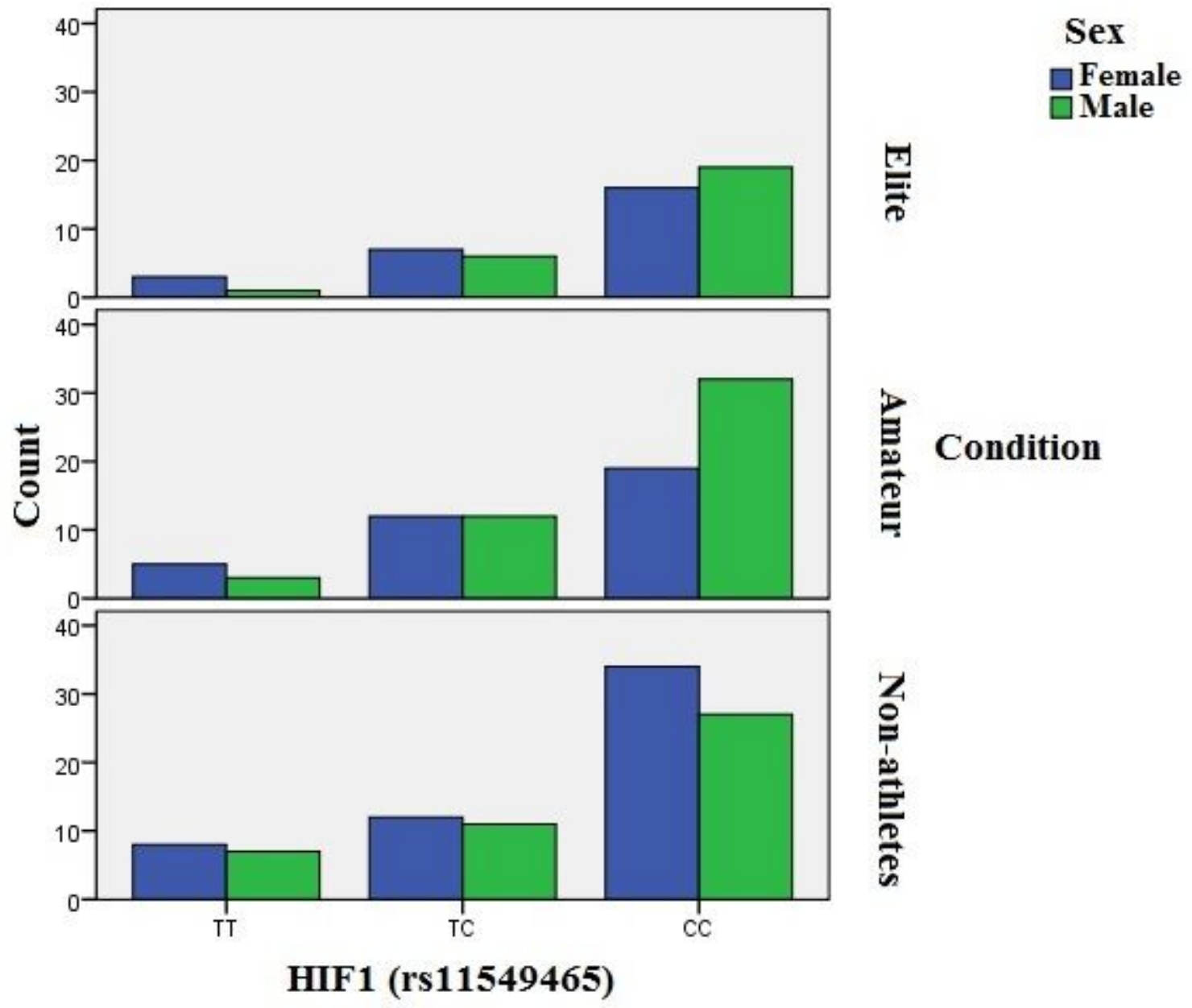

Figure 3

It shows simultaneous bar plot of female and male HIF1 allelic in different conditions: elite, amateur and non-athlete. 